\title{
Exploring Indigenous Consciousness: A Critical Study of the Oraon Folktale "The Enchanted Mandolin"
}

\author{
Ms. Juhi Rose Vandana Minz
}

Ph.D. Research Scholar, Centre for English Studies, Jawaharlal Nehru University, New Delhi and Assistant Professor, Department of English, Birsa College Khunti, Ranchi University.

Received: 16 Sep 2021; Received in revised form: 18 Oct 2021; Accepted: 23 Oct 2021; Available online: 31 Oct 2021 (C)2021 The Author(s). Published by Infogain Publication. This is an open access article under the CC BY license (https://creativecommons.org/licenses/by/4.0/).

\begin{abstract}
Folklore encompasses the tradition, culture, knowledge and teachings of a particular community. It often carries within it the worldview of the people of that community. The paper attempts to investigate a particular folktale of the Oraons, a tribe originally inhabiting the Chhotanagpur plateau, on the eastern part of India. Due to the prejudiced notion of tribe in India and the world, folklore, though theoretically has been referred to as verbal art but practically it has still not been accorded the status of literature. An absolute and comprehensive understanding of folklore necessitates the study of the folk as well. The present paper attempts an analysis of the Oraon folktales within the ambit of the cultural life of the Oraons. The paper attempts to question the binaries of barbaric and civilized, primitive and advanced while exploring the indigenous consciousness through the folktale.
\end{abstract}

Keywords - folklore, ethnocentrism, binary opposites, cannibalism, superstition, symbolism.

\section{INTRODUCTION}

Folklore has contributed enormously in comprehending indigenous cultures or for that matter any culture per se. Alan Dundes used the term "autobiographical ethnography" while referring to the characteristic of folklore as reflective of the culture of a country or a community. Even with all its alterations and transitions folklore would be closer to reality than any of the works of sociologists and anthropologists (55). To be acquainted with the culture of a country one should have a good understanding of not only the written texts but also the oral texts as it is the "symbolic language of the nonliterate parts of the people and the culture" (Ramanujan xiii). Folklore also has the distinctive feature of being the collective expression of the ideologies of the people of that culture. Thus if folklore is the delineation of a particular culture then its analysis has a lot of significance in bringing it within the realm of knowledge. But it would be wrong to assume that simply by studying folklore we would come to a holistic understanding of the culture of a particular community. The indigenous communities in India have undergone considerable changes since the documentation of the very first anthropological works. We should understand that apart from a literary study an anthropological and ethnographical study is also important pertaining to the present indigenous societies in India which have changed considerably post-independence. The paper would attempt to retell and critically examine the Oraon folktale. Discussing the binary oppositions of savage and civilized, the paper would seek to examine the relevance of superstition in Oraon culture through the various folk motifs inherent in it.

\section{THE TRIBES OF CHOTANAGPUR}

Jharkhand in eastern India is a land of thirty two different tribes. Some of them are the Oraons,the Mundas, theSanthals, the Hos and so on. These tribes are not just settled in Jharkhand but in adjacent states as well. The Chotanagpur plateau region is considered as the adivasi/indigenous belt of India.These indigenous communities have existed in harmony with each other since the precolonial era and they share a very opulent cultural heritage. This culture finds expression in their 
folklore consisting of tales, myths, proverbs, dances and the beautiful songs composed by them. For most of the indigenous people in this region, religious practices basically involve the worship of nature and they follow the animistic tradition. The languages spoken by the adivasi people in the Chotanagpur region are Mundari, Kurukh, Santhali, to name a few. For communication among the different tribes and also with the non-indigenous people a connecting language called Sadri is used. According to JavedAlam "most of these tribes..... do not as yet have a written language or a common literary tradition. But they are rich in folklore and around this a common culture and literary tradition is claimed to be taking shape" (194). The people from these indigenous communities capture and retain their experiences through songs and stories. Even if they do not have written texts their oral traditions of songs, stories, myths, proverbs and riddles can all be considered as oral texts because they have some significance for the culture they represent.The folktale of the enchanted mandolin is a very popular tale among the Oraons. Derived from the vast and rich collection of folklore of the Oraon tribe, the tale is told usually as a form of entertainment but it carries within it a reflection of the worldview and indigenous consciousness of the Oraons.Even though a lot of oral versions have been collected this version is derived from the translation of Oraon folklore by A. Grignard, from the book "Hahn's Oraon Folklore in the Original".

\section{THE FOLKTALE OF THE ENCHANTED MANDOLIN}

A family consisted of five siblings, four elder brothers and a sister. The brothers toiled in the fields while the sister stayed at home to prepare food for them. One day while preparing lunch for her brothers she cut her finger with the knife. Scared that the brothers will be displeased if they find blood stains in the house she wiped the blood on the vegetables and cooked it. The brothers found the food very delicious and asked the sister what she put into it. She confessed having put her blood in it. The brothers thought that if her blood was so tasty how delectable would her flesh be. The three elder most brothers connived with each other to kill the sister. So one day, they led her astray towards the forest and on reaching upon a suitable place they made her sit on a high platform and in order of their birth started shooting arrows at her. But they purposely missed the girl as they did not want the blame on them. When the youngest brother's turn came they threatened him that if his arrow missed the sister they would kill him too. Terribly frightened the youngest brother shot the sister and the girl died instantly.
Now the youngest was forced to chop and cook the sister's body because it was his arrow that killed her. The brother, weeping, ventured further in the forest to find fuel to cook the flesh. He came across a snake who asked him the reason of his sorrow. The brother related the whole incident. The snake offered to help him by coiling around the wood so that it would be easy for the boy to carry it. Later the brothers found that they did not have water. They found a pot with a hole in it, so again the youngest brother was sent off to fetch water. Weeping all the way he came near a river where he met a frog who asked him the reason of his sorrow. He related the whole incident. The frog offered to help the boy by covering the pot hole. The boy caught some crabs and fish from the river and returned back. He cooked his sister's flesh and bones and also the fish and crabs. When the elder brothers ate the flesh the youngest ate the fish and when they chewed the bones he chewed the crabs. When the elders had finished eating the youngest brother quietly buried his share of flesh and bones into an anthill.

With the passage of time a bamboo tree sprang from the anthill. One day a mendicant was passing through this bamboo tree. He heard the voice of a young girl coming from the bamboo grove so he decided to cut the bamboo and made a mandolin with it. Then playing the mandolin he went from house to house in order to beg. When he reached the house of the elder brother and played the mandolin a voice came out of it saying: "Don't ring, don't ring o mandolin: this is a culprit's house". The voice from the mandolin repeated the same thing at the houses of the other two brothers. When the mendicant arrived at the youngest brother's house and played the mandolin, a voice was heard which said: "Ring, ring o mandolin: this is the small brother's house". On hearing this, the youngest brother came out and brought the mendicant into his house. He served him rice beer till the mendicant was completely intoxicated and out of his senses. Then he hid the mendicant's mandolin and replaced it with another one. And from that day onwards whenever he played the mandolin himself his sister would appear in a living form in front of him. One day the youngest brother invited the three elder brothers to his house. When they were all seated to have their meals, the sister appeared, wearing white shining dress surrounded by light, to serve food to her brothers who fell on their backs with astonishment and fear.

\section{ANALYSIS OF THE FOLKTALE}

The folktale of the enchanted mandolin has a lot of variations in the Oraon folklore. Being oral such variations are bound to exist as story tellers tend to add new plots or 
modify characters based on the demands of the audience. But no matter how many changes are made the motif and structure of the tale would be consistent because it is here that the essence of the folktale lies. Stith Thompson in his book "The Folktale" describes a motif as "the smallest element in atale having apower to persist in tradition. In order to have this poweritmust have something unusual and striking about it" (415).The folktale under consideration has three motifs which hits the reader on the face. The first is the eating of human flesh, the second is the voice of lament coming out from the mandolin and the third is the resurrection of the dead sister. To an outsider or a non-indigenous person such a folktale would seem bizarre. But for the Oraons it has manifold signification. In order to delineate the Oraon folktales we must have a clear understanding of the Oraon society as a whole because the quintessence of these folktales lies very much engraved in the norms and practices of the Oraons. The Oraon society is a closely bonded society with a distinctive social organisation of its own. Till about a century ago almost no intermingling with outsiders occurred. Though, recently the tribe has undergone a lot of change. The tribe is further divided into clans. Each of these clans is distinguished by the totem which the clan ascribes to. The behaviour of people within the tribe is governed by tribal laws and taboos. The adherence to these laws and taboos guarantees the safeguard of their exquisite culture. Having no written tradition, the Oraons have to go an extra mile to preserve the laws and protect the culture. The culture is preserved through the practise of the rites and rituals in the numerous socio-religious ceremonies. The tribal laws and taboos are promulgated through the oral narratives. Thus in a way the folktale acts not only as a moralising tool but it is instructional as well.Certain norms are propagated while certain taboos are prohibited. The Oraons did not know of any written laws. They did not follow a constitution to decipher what is right and what is wrong. They could only fall back on the practical knowledge which they had gained through their ancestors, the knowledge which was acquired through the word of mouth. At this point we can consider another folktale of the Oraons which has a similar motif of cannibalism and the abstinence from eating the human flesh. A full retelling of the story would not be attempted and only the main motifs will be highlighted.

The story has four elder brothers and one little sister. The sister is kidnapped by a king while the brothers are busy hunting for food. While being taken away the sister tears off pieces of her garment to give a lead to her brothers who would search for her. On returning and not finding their sister the brothers did search for her, but it's the youngest who notices the rags on the ground. Following the torn pieces of cloth he reached the king's residence. As he entered the place, an old witch sitting in a corner turned him into a deer. The unfortunate boy ran towards the wheat fields and the villagers having caught sight of him, chased him and killed him. They brought some deer meat for the king as well. The sister had seen all that had happened and she refused to eat the meat. She said, "I will not eat human flesh." When the king enquired she narrated him the whole incident. Immediately the king asked for the remains of the brother. He put it in a heap and covered with a cloth and chanted some incantation. The boy was brought back to life.

As far as denouncing cannibalism is concerned the second folktale is important for the sister's strong refusal to eat "human flesh". It must be noted that she had seen her brother's ordeal, having been turned into a deer and finally killed. She was not only helpless to prevent it but was also fearful of the king. But when it comes to eating the meat, she vehemently refuses, without thinking of the consequences, saying, "I will not eat human flesh". The folktale thus tries to instruct that no matter what condition, cannibalism is strictly not acceptable in the Oraon tribal community.

The notions of the barbaric and the primitive have often been used with reference to tribes all over the world. It has been used by many great anthropologists and folklorists in the course of their study of the tribes. This construct is not just derogatory but it reeks of ethnocentrism. Further the theory of race proposed by Darwin speaks of there being a "less difference between the highest type of ape and the lowest of aborigines than there is between the latter and the modern English gentleman"(Bara 90).Such views with reference to tribes in general, point towards the fact that the indigenous people are considered to be backward and savage. To a prejudiced reader the act of cannibalism in the folktale under consideration may seem grotesque but the tone of the tale very clearly hints to the fact that cannibalism is not accepted in the Oraon society.

The concept of modernity and the idea of progressive, advanced, civilized societies have been created in the world from a very western or European perspective. The discourse related to the opposition of the East and the West is very much present in the global socio-political consciousness. The opposition between the cannibal and the civilized white has long been used to "establish racial boundaries"(Lidenbaum 493). Such oppositions need to be interrogated:

"The stigma of savagery and primitivism, it seems, is best countered when we forgo our attachment to metaphor to describe our own behaviours and reflect on the reality of cannibal activities among ourselves as well as others. We 
are then in a position to dislodge the savage/civilized dualism, once essential to the formation of a modern western identity and western forms of knowledge, as we fashion a new understanding of our postmodern self" (Lidenbaum 493).

Structures that assign meaning to certain practices as barbaric and others as civilized, need to be decentred. The grand narrative about civil society and primitive society needs to be questioned. Just because a particular community practices cannibalism or represents cannibalism in its folklore, this cannot signify that it is barbaric. The cultural practices of different communities around the world should not be analysed from an ethnocentric view but be understood in the context of the culture, tradition and ideologies of that particular community and the meaning such practises hold for its people.

No matter how shocking cannibalism is we have to understand it from a symbolic perspective. The callous devouring of the sister may be seen as being symbolic of the brutal reality of degeneration of land and people, which the Oraons and other indigenous communities have witnessed over the years. The sister being symbolic of land the elder brother can be seen as a metaphor of greed which leads to the exploitation of land. Once the elder brother in the tale comes to know of the unique quality of her sister's blood he is blinded by greed and he stops thinking rationally and goes on to kill her sister. He was definitely in a position of power being the eldest and he misused his power to further his greed. The sister represents the land. She has no agency over her body. She is voiceless and powerless. This is symbolic of how capitalist forces rob the land of its natural resources like forests and minerals. Interestingly while discussing cannibalism in contemporary culture Richard C. King draws a parallel between capitalism and cannibalism. Capitalism that is entrenched in exploitation and consumption of power is referred as "neocannibalism" (108).

The lamentation is another important feature of the folktale under consideration. This is usually composed on the death of a close relative or friend. In the book, Theory and History of Folklore, Vladimir Propp writes that when we talk of epics, lyrics and ballads, and their aesthetic characteristic, we must not leave out laments because "the power of the emotions they express makes laments part of lyric poetry"(31). Propp also points out that folk laments are different from other laments. Folk laments are direct and do not have symbolic or metaphorical significations unlike other laments. They reflect the biography of the deceased person. The lament in the folk tale under consideration is neither poetical nor reflective of the biography of the deceased sister. On the contrary the supernatural elements come into play and it is the dead sister's voice that laments her own killing at the hands of her elder brothers. This lament is just expressed in a single sentence, "Don't ring, don't ring o mandolin, this is a culprit's house" but it succeeds in revealing the misfortune of the murdered sister. The lament is also important when we perceive the folktale as a directive tool. The use of the word "culprit" in the lament is significant because it puts in the picture that murder and cannibalism are crimes in the Oraon society.

The third aspect of the folktale The Enchanted Mandolin is the resurrection of the dead sister. This motif of resurrection is also present in the second folktale. In both the folktales some supernatural power comes into play along with magic. Barbara Walker writes that "the realm of the supernatural is inextricably connected to belief, and belief is rooted near human cognition itself...... on which we may establish meaning and motivation for our lives." The definition of the word supernatural differs from individual to individual and from one society to another and there are communities in which a supernatural phenomenon is not an "extraordinary event", but an "other-worldly" phenomenon. Barbara Walker writes that:

"...if the supernatural is seriously considered, the events and phenomena reported or described within a group give us evidence of a particular way of perceiving the world. It provides insight into cultural identity and a greater awareness of the breadth and quality of human experiences and expressions. How groups regard the supernatural contributes to thought and behaviour, and by attending to those patterns, we gather a fuller understanding of what is meaningful to the group, what gives it cohesion and animation, and thus we develop a rounder perspective of cultural nuance, both within the group and cross-culturally" (2).

Belief in supernatural activities and magic is very central to the Oraon way of life. Religion and magic are a means of unravelling the complexities and mysteries of life and it is a way of finding meaning in their existence. Sarat Chandra Roy opines that the Oraonsare fearful of the mysterious supernatural powers and beings, and they pray to them to forestall their malicious intention and to secure their good will as far as crops, cattle, health and progeny is concerned.The folktale of the enchanted mandolin is reflective of this belief in supernatural activities. It brings to light their belief of the looming presence of the spirit of the dead relatives in their house and surroundings. The voice of the sister coming from the bamboo grove where she was buried hints to the presence of her spirit there. Further the appearance of the sister clad in a white dress 
blazing with light also insinuates the fact that it was her spirit that had appeared before her brothers. The Oraons do not part with their relatives even after their death. The reappearance of the dead sister may also hint to the belief of conducting a proper cremation ritual for their deceased ones. It is believed that the soul of the deceased relatives join the community of the pach-balar or ancestor spirits on the annual day of harbora or bone drowning, a ritual in which the bones of relatives who died during that year are deposited in the ossuary belonging to the clan of the deceased. Roy writes that:

...until this admission into the community of its dead ancestors, a recently departed soul sometimes seeks the company of its living relatives. But such visits, it is said, cannot last long. Many are the stories I have heard from my Oraon friends of the recently dead appearing apparently in flesh before their living relatives in their waking hours (21).

The notable point here is that the sister's bones, in the folktale, were buried in the ground without any ceremonies. This aspect may raise many questions in the mind of the young Oraons related to the appearance of the spirit of the sister. The bamboo grove which grew out of the spot of the burial of bones is also significant because of its symbolic characteristic. The bamboo, according to its biological attribute grows profusely and thus it symbolises prosperity and "continuity of the tribe; a life symbol"(Tirkey 89). Thus it is not surprising that the composer of the folktale uses the means of a mandolin made of bamboo to bring the sister face to face with her brothers. The presence of the witch, in the second folktale and the magic done to bring the brother back to life simply highlights their belief in both witchcraft and magic. The Oraons believe in the presence of the good spirit as well as the "evil eye" and "evil mouth" of certain individuals and to ward this off they indulge in the practice of a lot of religious ceremonies that also includes magic. Religion and magic together forms the "Oraon system of supernaturalism" (Roy 186). The Oraon uses folktales like the ones discussed above to pass on their beliefs and practices to their next generation.

\section{CONCLUSION}

Folklore being the perfect expression of the sentiments and ethos of the Oraon tribal community, its study becomes imperative in the modern world. The folklore of the Oraons which encompasses the folktales, folksongs, dance, proverbs, riddles and various myths are representative of their ideologies which have been shaped through generations and undergone a lot of transition. Thus undertaking a critical study and analysis of folklore is beneficial to bring this indigenous knowledge into the knowledge domain of the world. In addition to this the study of Oraon folklore would definitely contribute towards the advancement of cultural values of the Oraons. Sahab Lal Srivastava opines that folklore fulfils certain purpose and that is the reason why they survive in the particular community. These functions of folklore according to Srivastava are "recreation or amusement", "education", "socialization", "communication of knowledge", as a medium of popularizing and so on (276282). In the context of the Oraons the function of folktales is not just entertainment but a way of protest, revolution and instruction. The folktales are designed in such a way that the children are entertained and the youth are informed about the social condition.

\section{REFERENCES}

[1] Alam, Javed. (2003). "The Category of Non Historic Nations and Tribal Identity in Jharkhand." The Jharkhand Movement: Indigenous People's Struggle for Autonomy in India. Ed. R D Munda and S BosuMullik. Copenhagen: IWGIA.

[2] Bara, Joseph.(2009). "Alien Construct and the Tribal Contestation in Colonial Chhotanagpur: The Medium of Christianity." Economic and Political Weekly XLIV.52: 90-96.

[3] Dundes, Alan.(2007). "Folklore as a Mirror of Culture." The Meaning of Folklore: The Analytical Essays of Alan Dundes. Ed. Simon J. Bronner. Utah: Utah State University Press.

[4] Grignard, A.(1931).Hanh's Oraon Folklore in the Original. Patna: Superintendent Government Printing Press.

[5] King, Richard C.(2000). "The (Mis)uses of Cannibalism in Contemporary Cultural Critique". The Johns Hopkins University Press. Vol. 30, No. 1 Spring: 106-123. Print.

[6] Lidenbaum, Shirley. "Thinking About Cannibalism". Annual Review of Anthropology. Vol. 33 (2004): 475-498. Print.

[7] Propp, Vladimir.(1984).Theory and History of Folklore. Minneapolis: University of Minnesota Press.

[8] Ramanujan, A K. (1994). Introduction. Folktales from India. New Delhi: Penguin Books.

[9] Roy, S. C.(1984). The Oraons of Chotanagpur. Ranchi: Crown Publication.

[10] Srivastava, Sahab Lal. (1974).Folk Culture and Oral Tradition. New Delhi: Abhinav Publications.

[11] Thompson, Stith.(1946). The Folktale. New York: Dryden Press.

[12] Tirkey, Boniface.(1980).Oraon Symbols: Theologising in the Oaron Context. Delhi: Vidyajyoti.

[13] Walker, Barbara.(1995). Ed. Out of the Ordinary: Folklore and the Supernatural. Utah: Utah State University Press. 